\title{
MIR518E wt Allele
}

National Cancer Institute

\section{Source}

National Cancer Institute. MIR518E wt Allele. NCI Thesaurus. Code C105372.

Human MIR518E wild-type allele is located in the vicinity of 19q13.42 and is approximately 88 bases in length. This allele, which encodes MIR518E pre-miRNA, may play a role in the silencing of gene expression. 